Весна Дицков

Универзитет у Београду

Филолошки факултет
811.134.2(091)

https://doi.org/10.18485/climb.2017.5.1.ch4

\title{
ХИСПАНОАМЕРИЧКА КУЛТУРА У НАСТАВИ НА СРПСКОМ ЈЕЗИКУ
}

\section{Садржај}

Предмет овог рада је анализа присуства хиспаноамеричке културе у настави која се одвија на српском језику, пре свега на Филолошком факултету Универзитета у Београду. Постојећа грађа на српском језику (наставни програми, уџбеници, приручници) критички је сагледана у хронолошкој перспективи, са циљем да се укаже специфична својства ове материје, као и на могуће смернице будућег развоја поменутог сегмента наставе на високошколским установама у Србији.

Кључне речи: Хиспанска Америка, култура, цивилизација, настава, Србија.

\section{1. Историјат наставе хиспаноамеричке културе у Србији}

Почеци наставе хиспаноамеричке културе у Србији најуже су везани за појаву наставе шпанског језика и књижевности, организоване на факултативном нивоу 1951. године на Универзитету у Београду, у оквиру Катедре за романистику која се тада налазила под окриљем Филозофског факултета. Непосредно након осамостаљивања Филолошког факултета 1960. године као засебне наставне и научне установе, шпански у статусу другог страног језика постаје 1962. године изборни предмет на поменутој Катедри, а непуну деценију касније настаје 1971. године Група за шпански језик и књижевност, са студијским програмом од четири године. Увођење предмета хиспаноамеричка књижевност 1980. године доводи до промене назива и настанка Групе за шпански језик и хиспанске књижевности. На самом 
крају XX века, долази 2000. године до стварања самосталне Катедре за иберијске студије у чијем саставу се налазе Група за шпански језик и хиспанске књижевности, Лекторат за португалски језик и Лекторат за каталонски језик.

Силвија Искиердо-Тодоровић, Перуанка која је дипломирала шпански језик и књижевност на Великом националном универзитету Сан Маркос у Лими а цео свој радни век од 1970. до 2010. године провела на Филолошком факултету у Београду најпре као лекторка и потом као виша лекторка, држала је часове из предмета Увод у хиспаноамеричку цивилизацију за студенте треће године Катедре за иберијске студије. Након доношења Закона о високом образовању 2005. године, нарочито 2006. године, Филолошки факултет у Београду је прихватио принципе Болоњског процеса, те уобличио наставу у оквиру акредитованог студијског програма „Језик, књижевност, култура“ који је посвећен изучавању страних филологија, књижевности и култура, као и опште књижевности са теоријом књижевности, опште лингвистике, библиотекарства и информатике. Сходно томе, 2006. године на основним академским студијама уведени су предмети Хиспанске културе 1 (први семестар), Хиспанске културе 2 (други семестар), Хиспанске културе 3 (трећи семестар) и Хиспанске културе 4 (четврти семестар) који су обавезни за студенте прве, односно друге године на Катедри за иберијске студије, а могу по слободном избору да их похађају и студенти са свих осталих студијских профила програма „Језик, књижевност, култура“ на Филолошком факултету. Предмет Хиспанске културе 2 у целости је посвећен хиспаноамеричкој култури, док се предмет Хиспанске културе 4 бави основама шпанске и хиспаноамеричке кинематографије; предмети Хиспанске културе 1 и Хиспанске културе 3 усредсређени су на шпанску културу уопште и Златно доба (Edad de Oro), односно раздобље XVI и XVII века. Поједини елементи хиспаноамеричке културе обрађују се на часовима из предмета Увод у хиспанистику 1 (први семестар) и Увод у хиспанистику 2 (други семестар), који спадају у обавезне предмете за студенте прве године основних академских студија уписаних на Катедри за иберијске студије.

Мастер академске студије на Филолошком факултету Универзитета у Београду обухватају, у оквиру студијског програма „Културе у дијалогу“, предмет Хиспанска Америка и међукултурни дијалог, 
Култура и/или наука

доступан како домаћим тако и страним студентима који, у складу са својим личним и/или професионалним афинитетима, настоје да стекну специфична сазнања и вештине из области прожимања култура различитих народа, иако њихово претходно основно академско образовање не мора нужно да буде филолошког карактера.

Крајем XX века, организована је настава шпанског језика и хиспанских књижевности и културе у осталим академским центрима у Србији; наиме, 1997. године почиње са радом Лекторат за шпански језик у оквиру Одсека за романистику на Филозофском факултету Универзитета у Новом Саду, а исте године је основана и Катедра за хиспанистику на Филолошко-уметничком факултету Универзитета у Крагујевцу.

Настава из предмета Хиспанска култура одржавана је на Филозофском факултету Универзитета у Новом Саду током три академске године почев од 2006/2007. до 2008/2009. и обухватала је два двосеместрална циклуса током којих су се обрађивале и наставне јединице из области хиспаноамеричке културе. Након скоро деценијског прекида, настава из поменутог предмета биће обновљена од наредне 2017/2018. академске године и биће намењена студентима треће и четврте године Одсека за романистику, а одвијаће се у оквиру четири једносеместралне целине од којих ће по две бити посвећене култури Шпаније, односно Хиспанске Америке.

На Филолошко-уметничком факултету Универзитета у Крагујевцу не постоји посебан предмет који се тиче искључиво наставе хиспаноамеричке културе, већ су елементи из ове области укључени у редовне часове које похађају студенти четврте године из два једносеместрална обавезна предмета - Хиспанска књижевност XVIII и XIX века (седми семестар) и Хиспанска књижевност XX века (осми семестар) - у складу са студијским програмом акредитованим 2011. године, док ће према програму акредитованом 2015. године већ од 2018/2019. академске године заживети нова два предмета Хиспаноамеричка књижевност I (седми семестар) и Хиспаноамеричка књижевност II (осми семестар) - који ће обухватати и часове о култури Хиспанске Америке.

Поред државних универзитета, хиспаноамеричка култура се изучава и на приватном Универзитету „Џон Незбит“ (некадашњи „Мегатренд") у Београду. Геоекономски факултет (Факултет за 
међународну економију) овог Универзитета негује макроекономски и мултидисциплинарни приступ, те поред проучавања економских наука, обухвата и проучавање географских својстава, историје, културе и језика одабраних региона, међу које спада и Латинска Америка. У склопу овог факултета је основан 2000. године Сектор за Латинску Америку и Карибе, на којем је заступљена и настава из предмета Латиноамеричке цивилизације на основним академским студијама, док су током прве деценије XXI столећа постојали сродни предмети Увод у латиноамеричку цивилизацију и Савремена латиноамеричка цивилизација на којима је наставу држала од 2001. до 2011. године Силвија Искиердо Тодоровић. Сектор за Латинску Америку и Карибе располаже библиотеком „Сесар Ваљехо“ која представља прву библиотеку посебно оформљену у Србији и на Балкану за потребе проучавања Латинске Америке. Факултет за културу и медије, који такође спада у окриље Универзитета „Џон Незбит“, гаји сличну наставно-научну оријентацију, те нуди својим полазницима прве године основних академских студија на сва три акредитована студијска програма (Менанџмент у култури и медијима, Новинарство и Односи с јавношћу) обавезан предмет Историја културе и цивилизације, у оквиру којег је један час посвећен „прекоатлантским“ цивилизацијама Олмека, Маја, Астека и Инка.

\section{2. Наставни програми}

Настава из предмета Хиспанске културе 2 изводи се на Филолошком факултету Универзитета у Београду у оквиру програма „Језик, књижевност, култура“ на основним академским студијама, са циљем да полазници савладају најзначајније појмове неопходне за самостално проучавање хиспаноамеричке културе. Овај предмет превасходно је конципиран са намером да студентима уписаним на Катедри за иберијске студије омогући стицање ширег културолошког знања ради целовитијег изучавања шпанског језика и хиспаноамеричке књижевности. У том смислу, студентима се пружа панорамски увод у општу културу Хиспанске Америке, а на часовима се обрађују следеће тематске јединице: разуђен географски положај, 
богато историјско наслеђе, демографски конгломерат, прехиспански супстрат и древне цивилизације аутохтоних народа (Mаје, Астеци, Инке), откриће и освајање Новог света, раздобље колонизације (друштвено-политичко устројство шпанских колонија на америчком тлу, оснивање првих образовних институција), борба за независност и формирање република, појава диктатура, главни токови у савременој хиспаноамеричкој књижевности и уметности (музика, сликарство, вајарство) и њихови најзначајнији представници. С обзиром на то да у склопу Катедре за иберијске студије већ једанаест година постоји Лекторат за португалски језик, а такође имајући у виду свеукупан поглед на мултикултуралан склоп Латинске Америке, у оквиру курса Хиспанске културе 2 обрађују се и наставне јединице посвећене Бразилу (географија, историја, уметност). Будући да је предмет Хиспанске културе 2 методолошки усмерен првенствено на исходе учења, нарочито њихове облике интердисциплинарног и практичног карактера, посебна пажња се посвећује самосталном истраживању полазника, које се остварује како индивидуалним тако и тимским радом на претраживању интернета и библиотечких каталога, те припреми и реализацији презентација одабраних тема на часовима. Овакав вид интерактивне наставе Хиспанских култура 2, који се примењује од почетка друге деценије XXI века, омогућава студентима - у комбинацији са теоријским усвајањем градива и панелним дискусијама - лакше стицање основе за будући самосталан рад.

Предмет Хиспанске културе 4, који такође чини саставни део акредитованог програма „Језик, књижевност, култура“ за основне академске студије на Филолошком факултету Универзитета у Београду, представља увод у хиспанску кинематографију и подстицај на даље упознавање са овом облашћу. У оквиру овог предмета студенти треба да развију способност да остварења шпанске и хиспаноамеричке кинематографије посматрају у контексту не само хиспанске већ и светске културне баштине, као и да овладају основном терминологијом коју ће потом да примењују у проучавању шпанског језика и хиспанских књижевности. Приступ учењу заснива се у великој мери на комуникацијском методу, те поред пројекција филмова обухвата презентације и разговор на часу о одабраној теми као и самосталан истраживачки рад (одлазак у кинотеку, претраживање 
интернета и библиотечких каталога). У наставном сегменту посвећеном хиспаноамеричком филму присутни су неки од најзначајнијих савремених стваралаца са тог поднебља: Алфонсо Apay (Alfonso Arau, Мексико), Клаудија Љоса (Claudia Llosa, Перу), Алехандро Гонсалес Ињариту (Alejandro González Iñárritu, Мексико), Дамјан Цифрон (Damián Szifrón, Аргентина), Хуан Хосе Кампанела (Juan José Campanella, Аргентина), Томас Гутијерес Алеа (Tomás Gutiérrez Alea, Куба), Хорхе Фонс (Jorge Fons, Мексико), Гиљермо дел Торо (Guillermo del Toro, Мексико), Леонардо Фавио (Leonardo Favio, Аргентина) и Луис Пуенсо (Luis Puenzo, Аргентина).

Предмет Хиспанска Америка и међукултурни дијалог, који постоји у склопу студијског програма „Културе у дијалогу“ акредитованог за ниво мастер студија на Филолошком факултету у Београду, има сврху да обезбеди студентима неопходне компетенције за наставак самосталног научно-истраживачког рада на пољу многоструких интеркултуролошких релација и упоредних изучавања. У том смислу, полазници овог курса треба да упознају, кроз историју развоја културе у Хиспанској Америци, сву разноликост култура на овом поднебљу, равноправност интеркултурних веза и њихово међусобно уважавање, као и да сагледају појаве акултурације као исхода шпанског освајања да би могли да проникну у бројне узроке и последице националног и културног препорода хиспаноамеричких нација у XIX и XX веку. Теоријска настава подразумева подробно тумачење и аналитичко бављење појмовима културне разноврсности и интеркултуралности, праћено критичким увидом у постојећу теоријску литературу посвећену различитим културама (националне, верске, организационе, академске, професионалне, жанровске, генерацијске, технолошко-комуникативне), које се могу испољити у више потенцијалних варијетета (усменом, писменом и дигиталном). Наставне јединице (преколумбовске цивилизације, шпанско освајање Америке, колонизација и акултурализацја Латинске Америке, борбе за независност и трагање за националним идентитетом, индијанизам и индихенизам као различити облици односа према домородачком елементу, национални идентитет у савременој хиспаноамеричкој књижевности, латиноамерички филм и интеркултурни дијалог) које се обрађују на часовима теоријске наставе представљају основу за потоњи самосталан рад студената у оквиру практичне наставе. 


\section{Култура и/или наука}

\section{3. Уџбеници и приручници}

\section{1. Уџбеници}

Двојезично посебно издање под насловом Introducción a la civilización latinoamericana - Увод у латиноамеричку цивилизацију, које је написала на шпанском језику Силвија Искиердо-Тодоровић а превела на српски језик Ана Крстић, објавио је 2005. године Универзитет примењених наука „Мегатренд“ у 400 примерака. Рукопис су препоручили за објављивање рецензенти проф. др љиљана Павловић-Самуровић и проф. др Слободан С. Пајовић, док је одлуком Комисије за издавачку делатност Универзитета примењених наука „Мегатренд“ (број 145/42 од 14.10.2005. године) одобрен за штампу и употребу у настави као уџбеник. Истичући у „Предговору“ да је поменута књига плод наставног искуства стеченог током дугогодишњег рада на Катедри за иберијске студије Филолошког факултета Универзитета у Београду, а потом и у оквиру Сектора за Латинску Америку и Карибе Геоекономског факултета Универзитета примењених наука „Мегатренд“, ауторка скреће пажњу будућим корисницима-читаоцима на основну намену и циљ овог дела:

Увод у латиноамеричку цивилизацију јесте уџбеник, који не тежи да буде књига историје цивилизације Латинске Америке, већ само да се тој тематици приближи, како би, на тај начин, младим студентима посебно, а и читалачкој публици уопште, учинио блискијом једну тако пространу, разноврсну и географски удаљену област. Једну област, за многе егзотичну, са хиљадугодишњом културом, која је прошла кроз различите периоде у свом друштвено-политичком, економском и културном развоју; која је примила разне утицаје других народа Европе, Азије и Африке, који су се међусобно стопили и узајамно обогатили, да би касније учврстила сопствени, латиноамерички идентитет.

Основнициљ књигејесте, најпре, утоме дастудентимада смернице у једном уређеном облику, како би проширивали своја знања у овој области, помажући им на јасан и прихватљив начин; на другом месту, циљ јој је да пробуди интересовање за проучавање једне тако сложене теме, као што је то латиноамеричка цивилизација.

(Искиердо Тодоровић, 2005: 3) 
Књига Увод у латиноамеричку цивилизацију (344 стр.) садржи „Предговор“, дванаест поглавља са одговарајућим белешкама, „Одабрану библиографију“, „Индекс табела“, „Индекс илустрација“ и „Индекс слика“. У првом поглављу „Увод у латиноамеричку цивилизацију“ приказане су основне географске, демографске, лингвистичке и религиозне одлике латиноамеричке цивилизације. Дуго поглавље „Претколумбовска Америка“ садржи кратак преглед најзначајнијих теорија о доласку човека на амерички континент и цивилизација древних народа који су насељавали ово подручје пре шпанског освајања, уз тумачење постојећих извора информација и назива научне дисциплине американистика (amercanistica). Tpeће поглавље „Mесоамерка" је посвећено преколумбовским културама из Централне Америке, Мексика и Антила (олмечка, сапотечка, ћићимечка, култура Теотиуакана). Ауторка се бави општим одликама најзначајнијих преколумбовских цивилизација (порекло и географски положај, градови, друштвено-политичка организација, религија, наука, календари и симболи, уметност, писмо и језик, књижевност, легенде, васпитање и образовање) у четвртом поглављу („Цивилизација Маја“) и петом поглављу („Цивилизација Астека“). Шесто поглавље „Културна област Анда" упознаје читаоца са главним културама (Ћавин, Паракас, Викус, Моће, Наска, Тиауанако, Вари, Ћиму) које су постојале у овом делу Хиспанске Америке пре појаве Инка, док је седмо поглавље „Цивилизација Инка“ у потпуности посвећено одликама инкаичке културе. Осмо поглавље „Открића“ говори о Кристоферу Колумбу и његовом открићу Америке, а поменути су још неки морепловци (Америго Веспучи, Васко Нуњес де Балбоа, Фернандо де Магелан, Хуан Дијас де Солис и др.) чија су путовања донела значајна открића током XVI века. Девето поглавље „Освајања“ првенствено говори о освајању Мексика и Перуа, а у мањој мери о освајањима других делова америчког континента (Централна Америка, Еквадор, Чиле, Боливија, Аргентина). Десето поглавље „Колонија“ садржи подробан приказ раздобља не само шпанске већ и португалске власти у Латинској Америци (организација колонија, облици владавине на Иберијском полуострву - Савет Индија и Уговорна канцеларија, политичке и верске установе у Америци, вицекраљевства, португалска колонизација Бразила, становништво Западних Индија и Бразила, верске мисије и 
Култура и/или наука

покрштавање Индијанаца, културни живот). У једанаестом поглављу „Независност колонија у Америци“ обухваћено је раздобље које је претходило проглашењу независности латиноамеричких земаља (побуна Тупака Амаруа и други устанци, хероји ослободилачких ратова). Дванаесто поглавље „Република“ нуди панорамски преглед свих држава Латинске Америке (стварање, актуелна ситуација, културни живот, славни интелектуалци).

Introducción a la civilización latinoamericana-Увод у латиноамеричку цивилизацију Силвије Искиердо-Тодоровић је једини уџбеник у целости посвећен искључиво хиспаноамеричкој култури и, при томе, једино двојезично издање такве врсте које је до данас настало и изашло у Србији, те стога представља посебно дело од трајне вредности у оквиру српске академске литературе.

Далибор Солдатић и Жељко Донић су творци уџбеника Свет хиспанистике: увод у студије, који је објавио 2011. године Завод за издавање уџбеника у тиражу од 1000 примерака; рецензију овог дела урадиле су проф. др Јелена Филиповић и проф. др Јасна Стојановић. Иако су књигу Свет хиспанистике наменили првенствено студентима прве године основних академских студија уписаним на студијски програм „Језик, књижевност, култура“ у оквиру Групе за шпански језик и хиспанске књижевности при Катедри за иберијске студије Универзитета у Београду, као и студентима Филолошко-уметничког факултета Универзитета у Крагујевцу са циљем да им олакшају упознавање са специфичностима културе шпанског језичког подручја, аутори су такође настојали да овом књигом представе и својеврстан водич свима онима који су заинтересовани да стекну и/или прошире своја сазнања из области хиспанистике. Имајући у виду вишестрану концептуалну и наменску оријентисаност поменутог дела а с обзиром на едукативну хетерогеност полазника студијског програма „Културе у дијалогу“ на мастер академским студијама Филолошког факултета у Београду, књига Свет хиспанистике се користи и као универзитетски уџбеник на предмету Хиспанска Америка и међукултурни дијалог.

Стојећи на становишту да се језик и књижевност у одређеним друштвеним, историјским, политичким, економским, и наравно културним контекстима, аутори су покушали да студентима укажу на неке од кључних тренутака у историјском развоју Шпаније - шпанске 
државе и Хиспанске Америке, као и на поједине специфичне околности у којима се рађа уметност на шпанском говорном подручју.

(Солдатић и Донић, 2011: 5).

Уџбеник Свет хиспанистике: увод у студије (375 стр.) се састоји од „Уводне напомене“ у којој аутори укратко говоре о сврси овог дела, десет поглавља (Солдатић је аутор I, II, III, IV, V, VI, VIII и X поглавља, а Донић је аутор VII и IX поглавља) и „Библиографије“ са подацима о коришћеној литератури. У првом поглављу „Хиспанистика у свету и у Србији“ протумачен је појам хиспанистике и указано је на корене, појаву и развој изучавања ове науке у свету, Србији и бившим југословенским републикама. Друго поглавље „Шпанија: нација и језик" садржи појашњења о хиспанској раси у целости, са тумачењем актуелне језичке ситуације у Шпанији и Америци. У трећем поглављу „Шпанија“ дат је сажет преглед историје ове иберијске земље од Средњег века до демократске транзиције осамдесетих година XX столећа, уз осврт на положај Шпаније у првој деценији XXI века. Четврто поглавље „Историја Хиспанске Америке“ нуди сублимиран приказ најзначајнијих историјских збивања у осамнаест хиспаноамеричких земаља. Пето поглавље „Средства информисања“ је посвећено улози телевизије, штампе, радија и електронских медија у Шпанији и десет земаља Хиспанске Америке (Мексико, Аргентина, Венецуела, Куба, Чиле, Колумбија, Перу, Боливија, Уругвај, Парагвај). У шестом поглављу „Најзначајније институције и књижевне награде“ су обухваћене основне информације о престижним књижевним наградама које се додељују у Шпанији („Сервантес“, „Надал“, „Алфагуара“) и на тлу Хиспанске Америке („Ромуло Гаљегос“, „Каса де лас Америкас“, „Хуан Рулфо“), као и подаци о угледним шпанским институцијама од врхунског националног и културолошког значаја. Седмо поглавље „Ликовне уметности у Шпанији и Хиспанској Америци“ доноси преглед корена хиспанске уметности уопште како од шпанске средњовековне традиције до авангардних праваца и савремених тенденција, тако и од прехиспанске баштине до истакнутих сликара и вајара XX века на америчком тлу. Осмо поглавље „Филм“ говори о најпознатијим остварењима шпанске и латиноамеричке кинематографије. Девето поглавље „Преглед историје хиспанске му- 
Култура и/или наука

зике" представља увод у порекло музичке уметности у Шпанији (почев од Средњег века до савремених токова) и Хиспанској Америци (од периода колонизације до XX века). Десето поглавље „Популарна култура“ упознаје читаоце са основним цртама главних, типично хиспанских елемената популарне културе (популарна музика у Шпанији и Хиспанској Америци, латиноамеричке теленовеле, борбе с биковима).

Упркос томе што су извори и подаци често били неуједначени и застарели а понекада и недоступни, аутори књиге Свет хиспанистике Далибор Солдатић и Жељко Донић су успели да савладају тежак задатак, користећи у великој мери - уз претходну проверу тачности - информације добијене са интернета, из дневне шпанске и хиспаноамеричке штампе. Резултат овог њиховог изузетног прегалаштва је књига која је постала веома драгоцен уџбеник, будући да за неке од студената представља први додир са културом и цивилизацијом народа шпанског говорног подручја и суочавање са читавим низом појава и појмова недовољно познатих у нашој средини.

\section{2. Приручници}

Крајем XX века, Југословенско удружење латиноамериканиста је објавило два зборника радова са скупова одржаних током последње деценије XX века у Београду. Ове књиге се користе као приручници на Филолошком факултету у Београду за следеће предмете: Хиспанске културе 2 на основним академским студијама и Хиспанска Америка и међукултурни дијалог на мастер академским студијама у оквиру програма „Културе у дијалогу“. Поменути зборници имају - поред прилога састављених од резимеа на шпанском језику - двојезичне (на српском и шпанском језику) почетне, тј. насловне стране, садржаје и предговоре.

Зборник Латинска Америка и савремени свет, штампан 1995. године у 1000 примерака, обухвата радове са скупа „Пет векова Латинске Америке и савремени свет“ који су организовали јануара 1993. године Југословенско удружење латиноамериканиста и Институт за међународну политику и привреду из Београда, као завршну манифестацију обележавања петстоте годишњице открића Америке. Овај зборник (395 стр.), хетерогеног састава, садржи двадесет три рада који су

„[...] у распону од непристрасног изношења основних чињеница, преко утврђивања битних чинилаца даљег развоја, до 
проблематизовања неких његових токова и праваца, са посебним освртом на одређена тематска језгра, као што су модели политичких и привредних система, особености књижевног стваралаштва или домети уметности Латинске Америке уопште, а полазећи од парадигматског примера једне земље тог подручја."

(Леви 1995: 11)

Укњизи Латинска Америка и савремени свет учињен је покушај, по речима приређивача др Розите Леви из Института за међународну политику и привреду, да се обухвати и синтетизује развој латиноамеричког региона као целине, као и његових појединих земаља, са посебном пажњом која је поклоњена историјату освајања Јужне Америке. „Конкиста, као кључна тачка историје Латинске Америке, посматра се из различитих углова и њој је посвећено највише места у књизи." (Леви 1995: 11) Такође се указује на мултикултуралност латиноамеричког поднебља која проистиче из прожимања древних, аутохтоних цивилизација са шпанским и португалским наслеђем. Приређивач је успео да усклади текстове, тако да радови из овог зборника чине хомогену целину, подељену на три поглавља - „Лавиринти историје“, „Сусрет култура“ и „Дилеме развоја“ - чији је искључиви циљ „[...] да олакшају праћење, а никако, да строго омеђују и деле теме, јер би свака подела била недовољно прецизна и вештачка." (Леви 1995: 12)

Зборник Латинска Америка и савремени свет представља значајан допринос ширењу интересовања за ово подручје код нас, истиче приређивач, јер даје целовит поглед како на историју, тако и на развој савремене Латинске Америке, са мноштвом разноликих и ретких података који су приступачно и прегледно сабрани на једном месту (Леви 1995: 11).

Други зборник - Латинска Америка у двадесетом веку - који се користи као приручник у настави, самостално је издање (од 480 страна) Југословенског удружења латиноамериканиста из 1999. године, штампано у тиражу од 500 примерака; садржи тридесет радова, највећим делом потеклих са скупа одржаног 28. и 29. маја 1998. године у просторијама Привредне коморе Југославије, уз још неколико накнадно написаних прилога. Поменути скуп је организовало Југословенско удружење латиноамериканиста са намером да размотри битне особености (социјалне, политичке, економске, културне) 
главних токова латиноамеричке историје у XX веку. Приређивач Филип Матић, председник Југословенског удружења латиноамериканиста, груписао је радове у четири поглавља; „Основна обележја латиноамеричке историје“, „Привредни развој и интеграциони процеси“, „Мозаик латиноамеричке стварности“ и „Култура, књижевност, уметност“. На крају овог зборника дате су биографије аутора.

У „Предговору“ који су написали Филип Матић и Мило Петровић, истиче се да зборник Латинска Америка у двадесетом веку настоји да што целовитије сагледа једно историјско раздобље, те да није нити може бити биланс, нити дело у којем се на систематичан и конзистентан начин излаже, односно развија једно становиште, већ само делимични, каткад и летимични увид и поглед на збивања у Латинској Америци у XX веку, која се неизбежно различито тумаче, зависно од теоријског, идеолошког или политичког становишта истраживача. Узевши у обзир специфичне историјске и друштвено-политичке околности (велики демографски развој, повлачење диктаторских режима, демократска обнова) у којима се налазила Латинска Америка на истеку XX века, аутори предговора указују на то да овај зборник „[...] није производ усаглашеног рада једног тима професионалних научних истраживача, већ, изнад свега, резултат великих индивидуалних напора и ентузијазма његових коаутора, људи различитих професија, образовања, приступа и начина обраде тема“. (Матић и Петровић, 1999: 15)

Зборник Латинска Америка у двадесетом веку, чије је објављивање у нашим тадашњим приликама представљало - по речима аутора предговора (Матић и Петровић, 1999: 16) - прави подвиг, има трајну вредност јер, захваљујући својој тематској разноврсности, пружа читаоцима увид у веома широк спектар питања везаних не само за хиспаноамеричку, већ и за латиноамеричку културолошку стварност XX века.

\section{4. Завршне напомене}

Култура Хиспанске Америке је присутна у настави на српском језику од средине XX века, у склопу основних академских студија на Филолошком факултету Универзитета у Београду. Почетком осме деценије XX столећа, прерастањем Групе за шпански језик 
и књижевност у Групу за шпански језик и хиспанске књижевности дошло је до интензификације наставе хиспаноамеричке културе и појаве предмета ужег усмерења (Увод у хиспаноамеричку цивилизацију). Са усвајањем Закона о високом образовању 2005. године и прихватањем принципа Болоњског процеса, појавили су се на Филолошком факултету у Београду предмети како на основним (Хиспанске културе 2 и Хиспанске културе 4) тако и на мастер (Хиспанска Америка и међукултурни дијалог) академским студијама који су у целости посвећени хиспаноамеричкој култури, а доступни су свим заинтересованим студентима. Почетком XXI века, хиспаноамеричка култура постаје, такође, инкорпорирана у наставу на основним академским студијама на Универзитетима у Крагујевцу и Новом Саду, као и на београдском приватном Универзитету „Џон Незбит“.

Настава хиспаноамеричке културе на српском језику је заснована на методолошким и научним принципима који обезбеђују интерактиван приступ обради свих наставних јединица како на теоријском тако и на практичном нивоу, у складу са садржајима одговарајућих студијских програма. Сложени концепт ове области који указује на појаву мултикултуралности, акултурације, синкретизма и транскултурације на тлу Хиспанске Америке, условљен је суштинском карактеристиком хиспаноамеричког идентитета која проистиче из мешавине прехиспанског супстрата и шпанског наслеђа (ИскиердоТодоровић 2017: 432). Успешном извођењу наставе хиспаноамеричке културе у Србији знатно доприносе уџбеници и приручници домаћих аутора, објављени крајем прошлог и почетком овог века. Имајући у виду досадашњи веома динамичан развој наставе хиспаноамеричке културе код нас и велико интересовање студената за овом материјом, може се закључити да постоје чврсто утемељене основе и бројне могућности за даље унапређивање поменутог наставног сегмента, пре свега, на пољу компаративних културолошких изучавања.

\section{Извори и литература}

Izquierdo-Todorović, Silvia. Introducción a la Civilización Latinoamericana - Uvod u latinoameričku civilizaciju. Belgrado: Megatrend Universidad de Ciencias Aplicadas - Beograd: Megatrend univerzitet primenjenih nauka, 2005. Štampano. 
Култура и/или наука

Искиердо-Тодоровић, Силвија (2017): Izquierdo-Todorović, Silvia. “La cultura hispanoamericana en el Departamento de Lengua Española y Literaturas Hispánicas. Desde una perspectiva personal", y: Весна Дицков, (уредник). Идентитеm, мобилност и перспективе у студијама језика, књижевности и културе. Identidad, movilidad y perspectivas de los estudios de lengua, literatura y cultura. Београд: Универзитет у Београду, Филолошки факултет - Универзитет у КјетијуПескари, Одељење за пословну администрацију, 2017. 421-435. Штампано.

Latinska Amerika u dvadesetom veku. Beograd: Jugoslovensko udruženje latinoamerikanista, 1999. Štampano.

Levi, Rozita, (priredila). Latinska Amerika i savremeni svet. Beograd: Jugoslovensko udruženje latinoamerikanista - Institut za međunarodnu politiku i privredu, 1995. Štampano.

Matić, Filip i Milo Petrović. „Predgovor“, u Latinska Amerika u dvadesetom veku. Beograd: Jugoslovensko udruženje latinoamerikanista, 1999, 17-20. Štampano.

Солдатић, Далибор и Жељко Донић. Свет хиспанистике: увод у студије. Београд: Завод за уџбенике, 2011. Штампано.

\author{
Vesna Dickov \\ University of Belgrade \\ Faculty of Philology
}

\title{
HISPANIC AMERICAN CULTURE TEACHING IN SERBIAN
}

\section{Summary}

Taking into consideration that Hispanic America represents a conglomerate of nineteen countries, the culture of this extremely heterogeneous historical and geopolitical entity is characterized by special complexity. This paper is written with the aim to analyze the presence of Latin American culture in the educational process that takes place in the Serbian language, primarily at the Faculty of Philology, University of Belgrade. Existing teaching materials in the Serbian language (programs, textbooks, manuals) are thoroughly and critically examined in order to point out all specific features of the Hispanic American culture teaching in Serbia as well as to suggest possible directions for the future development of this teaching segment at higher education institutions in Serbia, especially in the field of comparative studies.

Key words: Hispanic America, culture, civilization, teaching, Serbia. 